\title{
Understanding financial innovation systems: Veblen and Minsky at the periphery
}

\author{
Solange Gomes Leonel, Sylvia Ferreira Marques, Ester Carneiro do Couto \\ Santos and Marco Flávio da Cunha Resende* \\ Department of Economics, Federal University of Minas Gerais, Brazil
}

\begin{abstract}
Setting off from an Evolutionary perspective, this paper debates key aspects of the process of financing innovation based on Keynes's asset choice model within the context of Minsky's cycle and the Institutionalist approach of Veblen. Innovative activity is surrounded by great uncertainty because firms invest funds for the long term without being sure whether they will earn high returns. As a result, firms run into additional obstacles when trying to obtain financing to develop new technologies. This difference becomes clearer when developed countries (USA) and less-developed countries (Brazil) are compared. The higher the level of uncertainty in world markets, the lower the amount of funds available to finance innovation; and this situation is accentuated in less-developed countries because they do not have a mature financial system capable of supporting innovation risks.
\end{abstract}

Keywords: financing innovation, uncertainty, asset choice, Veblen, Minsky

JEL codes: $E 12, O 16, O 43$

\section{INTRODUCTION}

Financial institutions, taken here as a social phenomenon, constrain firms' behavior. While struggling to fund their product and process innovation systems, firms interact within social and material structures. Thus, their behavior is shaped by these structures. This can be seen when one compares financial arrangements operating in central economies with those operating in the periphery. In central economies, such as the USA, agents' preference for low liquidity favors investments in asset innovation. On the other hand, the high degree of uncertainty in peripheral economies, such as Brazil, will decrease the strength of the institutions that can finance innovation and favor investments in liquid assets such as currencies. Therefore, the structure of financial systems can compromise market development and increase economic differences.

This paper aims to point out how international financial cycles affect investments in innovation and make this process more complex and difficult in economies whose National Innovation Systems (NIS) are less developed. It is based on Keynes's Asset Choice Model within the context of Minky's Cycle and Veblen's Institutional

* We are grateful to Marc Lavoie, Mario Seccareccia and Eduardo da Motta e Albuquerque for their valuable comments. Any errors or omissions are our own. Financial support from the National Research Council (CNPq) and FAPEMIG is gratefully acknowledged. 
perspective. This article is divided into five parts: (1) introduction; (2) Veblen's evolutionary institutionalism; (3) the relationship between uncertainty and innovation; (4) financing innovation at the center and at the periphery of international financial systems, according to Minsky's financial cycle and liquidity preference; and (5) conclusion.

\section{INNOVATION: AN INSTITUTIONAL ANALYSIS}

Supporters of evolutionary economics explain economic development through the innovation process. They believe that the economy is constantly mutating in an evolutionary process and that the diversity of agents interacting in the market leads to evolution through natural market selection. They also presuppose rationally-bounded economic agents acting within an uncertain environment. Agents adopt routines to guide their behavior, and such routines must be learned and internalized. So, the society's development path is based on firms' innovation-oriented routines that will allow them to survive in the market.

Innovation can be fostered by a National Innovation System (NIS) that alters firms' routines, and although there is no consensus as regards the concept of NIS, its meaning is clear to an evolutionary economist. In a broad sense, NIS can be understood as a 'well-articulated and verified analytic framework linking institutional arrangements to technological and economic performance' (Nelson/Rosenberg 1993: 4). Generally, the concept of NIS emphasizes that nations' technological progress is driven by a complex institutional arrangement consisting of educational systems, R\&D centers, universities, firms, and financial institutions (Suzigan/Albuquerque 2008). Due to the large number of actors in NIS, this paper focuses only on financial institutions.

According to Veblen (1961), agent (firms) and structure (financial institutions) are by-products of an evolutionary process. Agent and structure are co-constitutive, which means that one affects the other continuously in an ongoing process. Co-constitution is an ontological assumption in Veblen's institutionalism. It is postulated that actors are shaped by the social environment within which they are embedded. Thus, if on the one hand institutions will emerge from agents' routine behavior, on the other they will guide and define behaviors, purposes and goals. 'It is, of course, on individuals that the system of institutions imposes those conventional standards, ideals and canons of conduct that make up the community's scheme of life' (Veblen 1909: 629). Structure not only constrains agents' behavior but also affects their motivation.

Furthermore, the social complex of individual interactions constitutes a social stock of intangible knowledge - that is, institutions are repositories of social knowledge (Veblen 1909). From Veblen's point of view, institutions are social structures that involve customs and are embedded in a material environment. Individuals interact within this social and material environment.

Any community may be viewed as an industrial or economic mechanism, the structure of which is made up of what is called its economic institutions. These institutions are habitual methods of carrying on the process of the community in material contact with the material environment in which they live. (Veblen 1899: 193-194)

The type of innovation financing that firms seek or have access to is socially defined within this material environment where they interact. The financial structure 
that firms face reflects agents' interactions within the market and constrains its behavior. Procedures and results cannot be seen as separate phenomena, as they must be seen in cause-effect terms. This means that agents' intentionality must be understood in an evolutionary context (Veblen 1909). Knowledge of evolutionary science is based on causeeffect relations and intentionality is taken only temporally as an approaching factor, although always with reservations (Veblen 1961).

Rationality is neither unique nor unaltered; rather, it is shaped within a social context. According to Veblen (1961), although agents act rationally, the reasons and beliefs that guide their behavior must also be explained. Reason is driven by habit and instinct. Habits are understood as a propensity or a disposition towards behavior, and not as behavior itself. Instincts are biologically inherited and cannot be changed, while habits are socially acquired. Both instincts and habits are essential and complement each other. Veblen states that conscious deliberation involves habits and instincts and that actions guided by these elements do not contradict rational behavior.

Habit is not opposed to reason but part of the act of deliberation itself. In turn, the habit-driven capacity to reason and reflect upon the situation could give rise to new behaviors and new habits. Habits and reason can interact with one another in an ongoing process of adaptation to a changing environment. This capacity to form new habits, aided by both instincts and reason, has helped to enhance the fitness of human species in the process of natural selection. (Hodgson 2004: 167)

By analogy with Veblen, when firms seek funds to invest in their R\&D activities, they consider both routines and bounded rationality. According to Veblen's theory, routines are behaviors that are socially learned - that is, they can be defined as habit. On the other hand, bounded rationality cannot be socially changed; therefore it may be defined as an instinct. From an evolutionary point of view, skills and routines can be learned and improved through practice, creating competencies within changeable competitive patterns (Nelson/Winter 1982). These behaviors and competitive patterns are shaped by market structures, including the structure of financial systems, as well as by the constant presence of uncertainty.

\section{UNCERTAINTY AND INNOVATION}

Uncertainty and risk are interpreted in different ways from a post-Keynesian point of view. That is, the former cannot be calculated while the latter can be calculated considering probabilities assigned to several events. Furthermore, the concept of uncertainty is more dynamic while the concept of risk tends to be more stationary. Economic events must be measured through the concept of uncertainty, since the future does not yet exist and it is not possible to assign probabilities to it. Hence, if future probabilities could be assigned as past probabilities, the economic environment would be considered ergodic (Knight 1965; Amado 2000; Langlois 1994).

The ergodicity in economics presupposes that events are independent in time, which means that probability distributions do not change even if the period of time does. On the other hand, such a situation also implies that events should be perfectly reproducible and each experiment would have the same weight on the probability distribution. Moreover, it is necessary to take into account that possible results must add up to one to sustain the use of traditional probabilistic methods. Hence, an ergodic analysis of the economic environment produces a limited vision of future events (Amado 2000). 
The uncertainty concept is intrinsically related to historical time - that is, time goes from the past to the future in such a way that an agent's present decision affects future events. Thus, the future (1) cannot be estimated in a totally feasible way because it still has to be built and (2) cannot be guided by the ergodic process, as agents would not have a solid basis to make their decisions since the calculation of probability would reduce uncertainty to calculable risk and certainty equivalence (Keynes 1937).

According to the evolutionary approach, innovation is considered an activity of high uncertainty due to the impossibility of predicting the success of a new product or service. Even when it is possible to have a reasonable idea of successful innovation patterns, it is impossible to establish market reality and competitor behavior beforehand. According to Freeman and Soete (1997: 243), 'what can be recognized ex-post cannot always be controlled or initiated ex-ante.'

This uncertain environment where R\&D takes place creates a barrier to innovation financing in the productive sector. As per Hall (2002) and Carpenter and Petersen (2002), R\&D investments present particular features that make them different in comparison to other types of investments, such as: (1) on average 50 percent of the resources are spent on highly-qualified workers such as scientists and engineers; (2) the knowledge created is tacit, hence it is a complicated task to either dismiss or replace workers without significant losses while the project is being carried out; (3) return on investments is slow and uncertain, which increases the risk premium; and (4) information asymmetry between firm/innovator and investor makes it harder to select between good and bad projects. So, risk aversion agents tend to prefer short-term R\&D projects instead of long-term ones.

\section{FINANCING INNOVATION}

\subsection{Financial arrangements: asset choice and liquidity preference in Minsky's Cycle}

Added together, historic time, uncertainty and money make the latter an alternative asset to other forms of wealth accumulation, while liquidity preference plays a central role in determining the rate of employment in the economy. Thus, the agents' decision process is oriented not by rational expectation but by subjective and conventional elements (Amado 2000).

Keynes's asset choice model takes into account not only monetary aspects related to asset possession, but also the asset's liquidity degree and its premium. Therefore, it relies on the general principle that different liquidity degrees must be rewarded by pecuniary returns that define the rate of return obtained by the possession of different assets. So, each asset presents its own rate of interest, and wealth will be allocated to an asset with a higher own rate of interest.

The own rate of interest is defined by the total return that an asset to which it is associated offers to its owner. It is not confined to interest paid on income, as it also incorporates the convenience of possessing the asset and the capital gains it accrues when sold. The asset choice model is characterized by forward-looking operations, and it is related to the time horizon involved in the choice process. It is worth noticing that time is, by itself, a constant part of an asset's return.

Post-Keynesian theory defends that all assets have the same retention time so it is possible to compare between different assets with different maturation times and 
interest payment profiles. It does not mean that post-Keynesian theory does not take into account an asset's time dimension, since it is incorporated into each asset's liquidity premium.

According to chapter 17 of Keynes's General Theory, different degrees of liquidity must be rewarded by an asset's pecuniary returns (Keynes 1936). Thus, as Paula (1999) demonstrates, it means that each asset class has its own rate of interest defined in terms of current market prices. The own rate of interest is compounded by four attributes found in any asset. The first one is the quasi-rent rate that can be obtained by the asset's possession or use, designated by $q$. The second one is the carrying cost represented by $c$, which means that asset retention has a cost. The third one is related to the liquidity premium and it is indicated by $l$. High liquidity assets offer their owners an essential 'return' expressed by the flexibility provided in facing economic world uncertainties. The fourth one is represented by $a$ and it is related to the appreciation (or depreciation) of an asset over time. In other words, it is related to capital gains. So, an asset's own rate of interest can be summarized by the following equation:

$$
a+q-c+l
$$

In this model, uncertainty is reflected not only in the liquidity premium $l$ but also on the other terms of the equation. Each component responds in a singular way to an agent's expectations of change. There is a trade-off between monetary returns $(a+q-c)$ and the liquidity premium $l$. Uncertainty is responsible for changes to the four elements presented above and, consequently, for changes in the demand structure for assets that have different monetary returns and liquidity premiums. Considering it all, the next step is to understand how innovative assets operate, taking liquidity preference into account.

Economic agents choose to allocate their capital between liquid assets (money and other high liquidity assets) and illiquid assets - that is, assets that will immobilize their wealth for a while, such as innovative assets. Just like firms, financial institutions do not have any real assurance of assets' return or appreciation. In other words, there is a non-probabilistic uncertainty about the future. Therefore, agents' liquidity preference will decide investment resources' allocation to a liquid or illiquid asset.

When expectations are favorable for risk-taking, the weight of the liquidity premium is low. So they are encouraged to put their wealth into riskier assets such as technological innovation. In this case, the illiquid asset's own rate of interest is higher than that of the liquid assets. This situation can be represented by

$$
a_{i}+q_{i}-c_{i}+l_{i}>a_{m}+q_{m}-c_{m}+l_{m}
$$

where the subscripts $i$ and $m$ refer to innovative assets and money, respectively. It is worth noticing that the liquidity preference determines the relative weight assigned to each component of the asset's own rate interest. Should agents be pessimistic about the future, the weight assigned to $l$ would be higher. Hence, agents would concentrate their wealth into liquid assets such as money, since its own rate of interest would be higher than the one offered by an innovative asset.

As Minsky (1986) points out, banks are active agents that interact in the monetary economy under restrictions similar to and facing uncertainty equal to or higher than that of other economic agents. This is due to the speculative nature of their balance sheet position. Banks and other financial institutions also have liquidity preference, and play a central role in establishing the liquidity and financing conditions of an economy. 
They affect firms' decisions about carrying out technological innovations. It is easy to see here the behavior constraints Veblen alleges financial systems impose on firms.

The behavior of financial institutions partly explains the economic cycle in both an economic boom and in a period of crisis. For example, if the market is less conservative, financial institutions relax their criteria based on the value of assets pledged to grant credit, and therefore they will prefer illiquid assets with long-term returns. So, profitability tends to be the main criterion sought by banks that take a Ponzi position (Paula 1999). Since banks' liquidity preference is low, assets are chosen on the basis of their rent - that is, on their appreciation of $a$ and their quasi-rent $q$. In such a situation, carrying costs $c$ tend to remain relatively constant while the liquidity premium $l$ will fall. However, in moments like this, banks' indebtedness tends to rise substantially - that is, every time apprehension replaces euphoria the descendent phase of the economic cycle will begin.

On the other hand, if markets grow more conservative, banks will emphasize expected cash flow as the main criterion to grant credit and assume a Hedge position. Thus, a preference for high liquidity on the part of banks makes illiquid assets less attractive. If the economic cycle enters a downswing, the $l$ component on the asset choice increases at the same time that its appreciation $a$ and quasi-rents $q$ tend to decrease. In this phase, the demand for credit cannot be met depending on the liquidity preference of financial institutions, on the conventional preference of economic agents, and on uncertainty. As uncertainty decreases, liquidity preference also decreases and banks tend to assume a Ponzi attitude. This situation contributes to stabilize the economic cycle.

According to Minsky (1986), these behaviors may be interpreted as natural phenomena of financial markets, as they are responsible for switching an economic cycle from euphoria to depression and vice versa. Dow (1993) argues that different economies present different liquidity preferences, since the expectation of lenders as regards returns on assets will change from country to country. Dow (1993) also states that Minsky's cycle operates in the same way both in national and in international financial systems. The difference between economies located at the periphery of international financial systems and economies located in the core of the systems lies in the fact that the former present: (1) a lower perspective of growth and/or higher probability of deficit in current accounts; (2) a lower marginal efficiency of capital; and (3) a higher liquidity preference. Therefore, the economies of less developed countries tend to depend more heavily on external finance.

Dow (1993) demonstrates that international financial systems follow Minsky's cycle in each economy. In moments of euphoria and economic growth, capital flows in international markets are driven to riskier assets that, despite their lower liquidity, will offer higher profitability. Still, if there is an expectation of capital loss, international financial systems tend to be more conservative in providing credit to riskier assets. Generally, a peripheral economy will find it very difficult to finance its external liabilities, and so it will tend to experience recurrent currency crises. Thus, international financial systems are neither impartial nor neutral. Capital flows affect economic systems and create income disparities between nations.

Resende (2005) and Resende and Raposo (2008) reinforce this argument. They have shown that countries with a well-structured NIS are more capable of pushing the knowledge envelope curve further in different areas. Consequently, the greater the industrial diversification, the wider the export basket and the higher the generation of foreign exchange. If the economy has a less mature NIS, its industrial structure tends to be less 
developed and its internal demand must be supplied by imported goods. As a result, the income elasticity of demand for exports tends to be lower than the income elasticity of demand for imports which leads to an external structural vulnerability.

The external vulnerability of peripheral countries stems from the fragility of their domestic institutions, which are unable to gain the trust of agents if uncertainty persists. Thus, investments in innovative assets become riskier in peripheral economies than in central ones. It is important to note that, regardless of Minsky's Cycle in the context of open economies, financial institutions consider the following relation when choosing to allocate their resources:

$$
a_{c}+q_{c}-c_{c}+l_{c}>a_{p}+q_{p}-c_{p}+l_{p}
$$

where attributes $c$ and $p$ describe the central economy and the peripheral economy, respectively. Considering the same assets class - it can be an illiquid asset like an innovative asset or a more liquid one like a currency - the own rate of interest of an asset in a central economy will always be higher than that of the same asset in a peripheral economy. It is a fact that the structure of financial systems affects cash flows and credit grants within an economy and between economies. However, in moments of euphoria in the world economy, the difference between the own rate of interest of innovative assets in peripheral and central economies will fall. In such a case, liquidity preference and risk aversion will be at their lowest. Thus, peripheral countries, where the NIS is immature, should take advantage of moments of euphoria in the world economy to raise investments in innovative assets in the periphery. The post-Keynesian explanation about asset choice and liquidity preference within the context of Minsky's cycle partially explains why developed countries are always on the boundary of technological knowledge compared to peripheral countries. However, according to Veblen, the behavior of agents is set endogenously by the social environment and so it is important to understand how the structure of financial arrangements affects the funding of innovative firms.

\subsection{Financial arrangements in developed countries: sources of funding for innovative firms}

In his Theory of Economic Development (1911 [1934]), Schumpeter discusses the importance of credit systems on the funding of firms that will introduce revolutionary changes in the market. The author also highlights the role of bankers as links between firms that want to innovate and those that have factors of production. It is important to note that the stage of firm development (Table 1) can determine their access to finance.

Therefore, it is clear that the behavior of economic agents is limited by structures. Firms that are in the sustained growth stage obtain credit to finance innovative assets more easily than those in the start-up stage. In countries with a well-structured NIS, this distortion can be corrected through alternative financial arrangements (Figure 1).

Roberts (1991) offers an analysis of financial arrangements that can be accessed in each one of the three stages of firm development:

- Personal savings and family and friends funds are probably the most easily available sources of capital. However, they are not always enough to pay for $\mathrm{R} \& \mathrm{D}$ activity, infrastructure and salaries. The main disadvantage of family and friends funds is that friends and relatives often not only feel part of the business but also feel they have the right to interfere with management. 
Table 1 Stages of firm development

\begin{tabular}{ll}
\hline Stage & Feature \\
\hline Start-up & It starts with few customers; \\
& The firm is housed in modest facilities; \\
Typically, it has great technical knowledge, but an inexperienced \\
management team; \\
It has little or no collateral to raise loans; \\
The firm is not operating profitably. It needs capital to finance \\
product development and infrastructure, and to pay salaries. \\
The firm becomes more attractive to potential investors; \\
It is profitable, but cash flow is insufficient to support future \\
investments; \\
The risk and uncertainty associated with the business lessens; \\
The demand and complexity of operations increase; \\
Initial growth \\
Annual sales reach millions of dollars and it employs hundreds of \\
people; \\
It has sufficient cash flow to invest in innovative assets; \\
It has easy access to long-term financing; \\
The firm serves many companies and offers a variety of products \\
and services.
\end{tabular}

Source: Adapted from Roberts (1991).

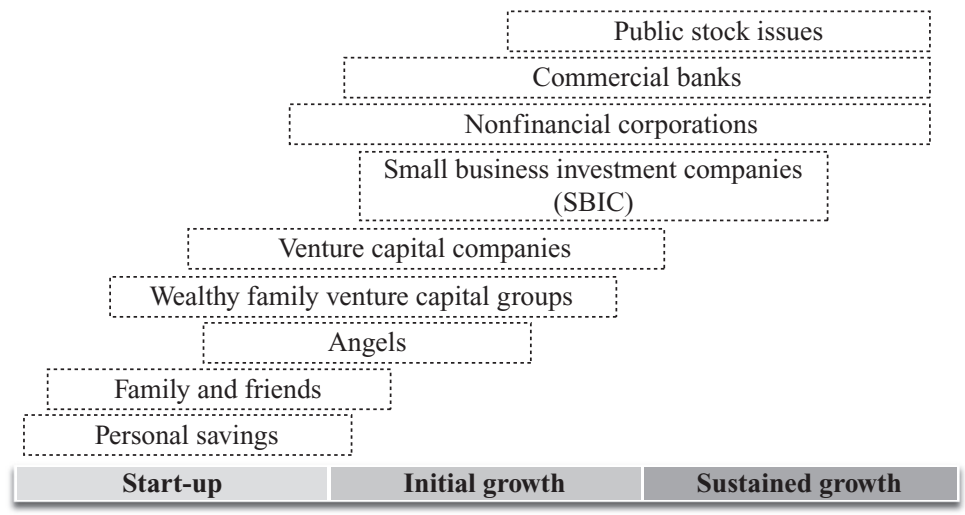

Source: Adapted from Roberts (1991).

Figure 1 The USA financial base

- Angels are private individuals who invest their own funds in start-up and initial growth companies. They are particularly motivated by non-economic factors such as participation in an exciting growth firm with bright young people.

- Wealthy Family Venture Capital Groups are formal private venture capital investment groups established by wealthy families. Those groups, for example 
the Rockefeller family, became more prominent after World War II. Their aim is to diversify their portfolio by investing in great ideas. Although their resources are essentially unlimited, they invest in less than 1 percent of all the proposals they receive.

- Seed capital and Venture Capital Companies are set up by wealthy individuals, banks, pension funds and corporations. Besides money, they offer expertise in a broad range of subjects such as management, finance, and accounting. They only invest in firms with high potential to achieve outstanding financial returns. This represents 2 percent of the proposals they receive. Seed Capital is invested at the initial stage of the new firm while Venture Capital investment occurs after the seed funding round. Venture Capital is interested in obtaining returns through a possible initial public offer (IPO) or trade sale of the company.

- Small Business Investment Companies (SBICs) are a special form of venture capital fund found in the USA. This kind of fund (for example, Bank of Boston Venture) receives tax incentives to invest in small businesses. It does not necessarily invest exclusively in technology-based firms.

- Nonfinancial Corporations are headed by large economic groups, such as DuPont, Ford, Texas Instruments, and Monsanto. Many of them invest in young technology-based firms to supplement their in-house R\&D activities. One disadvantage is that non-financial corporations may tend to interfere in the management of young firms.

- Commercial Banks provide short-term capital. They are more active as co-sponsors through SBICs and venture capital.

- Public Stock Issues allow companies the necessary liquidity to finance R\&D and expansion projects. However, when the market is more conservative it becomes very difficult for the firm to raise public funds.

According to Carpenter and Petersen (2002), venture capital and public stock issues are the form of equity financing that are currently best suited to ensuring the comparative advantage of nations in the production of high-tech goods. Widespread in the USA, these financial arrangements are considered more efficient because firms can invest in innovative assets without going into debt. Caprio Jr and Demirgüç-Kunt (1998) say that firms seem to grow faster than when using only internal resources and short-term loans when there is an active stock market and when creditors and debtors are able to agree on long-term contracts.

Although Roberts (1991) does not include governmental support in his analysis, it is important to mention that many $R \& D$ projects carried out by firms are financed by governments. To Fabrizio and Mowery (2007), government investment funds in the USA were responsible for accelerating the growth of firms in the Information Technology sector after World War II, which led to the emergence of many important firms.

Lamoreaux and Sokoloff (2007) outline that American success stems from the evolutionary process institutions have gone through over the past 200 years. In moments of great uncertainty in the world market, the strength of American institutions translates into the confidence of investors who allocate their resources according to the preference relation of equation (4.3). Furthermore, in a well-developed financial system it is possible to turn an illiquid asset into a liquid one by securitizing it. Obviously, in less-developed countries, where firms face structural problems in the financial arrangements available and where uncertainty and liquid preference are higher, financing $\mathrm{R} \& \mathrm{D}$ projects is a challenge that must be overcome. This is the problem Brazil faces, as described below. 


\subsection{Brazil: an overview of financing innovation}

It is important to take a look at the obstacles faced by innovative Brazilian firms to understand Brazil's position compared to other competitors. According to the Brazilian Survey of Technological Innovation (Pintec) carried out in 2008 by IBGE, the percentage of innovative companies with problems or obstacles stands at 49.8 percent. This proportion is structured as follows: 49 percent of industrial companies, 54 percent of selected services, and 79 percent of R\&D companies reported problems or obstacles.

Figure 2 shows that among the three sectors considered - industry, selected services, and $\mathrm{R} \& \mathrm{D}$ - the four main obstacles were the same, varying only in size and placement. Three of them are economic (high innovation costs, high economic risks, and few funding sources) and one is internal to firms (lack of qualified personnel).

In industry, the first-place obstacle was high innovation costs (73.2 percent), followed by high economic risks (65.9 percent), lack of qualified personnel (57.8 percent), and few funding sources (51.6 percent). In selected services, the main problem was a lack of qualified personnel (70.4 percent), followed by economic problems: high innovation costs (72.1 percent), high economic risks (62.6 percent), and few funding sources (48.7 percent). Lastly, in R\&D companies the negative highlights were high innovation costs (73.3 percent) and few funding sources (70.0 percent).

Despite all the obstacles listed by Brazilian firms, few funding sources confirm the thesis that the cycle of international financial systems affects investments in innovation

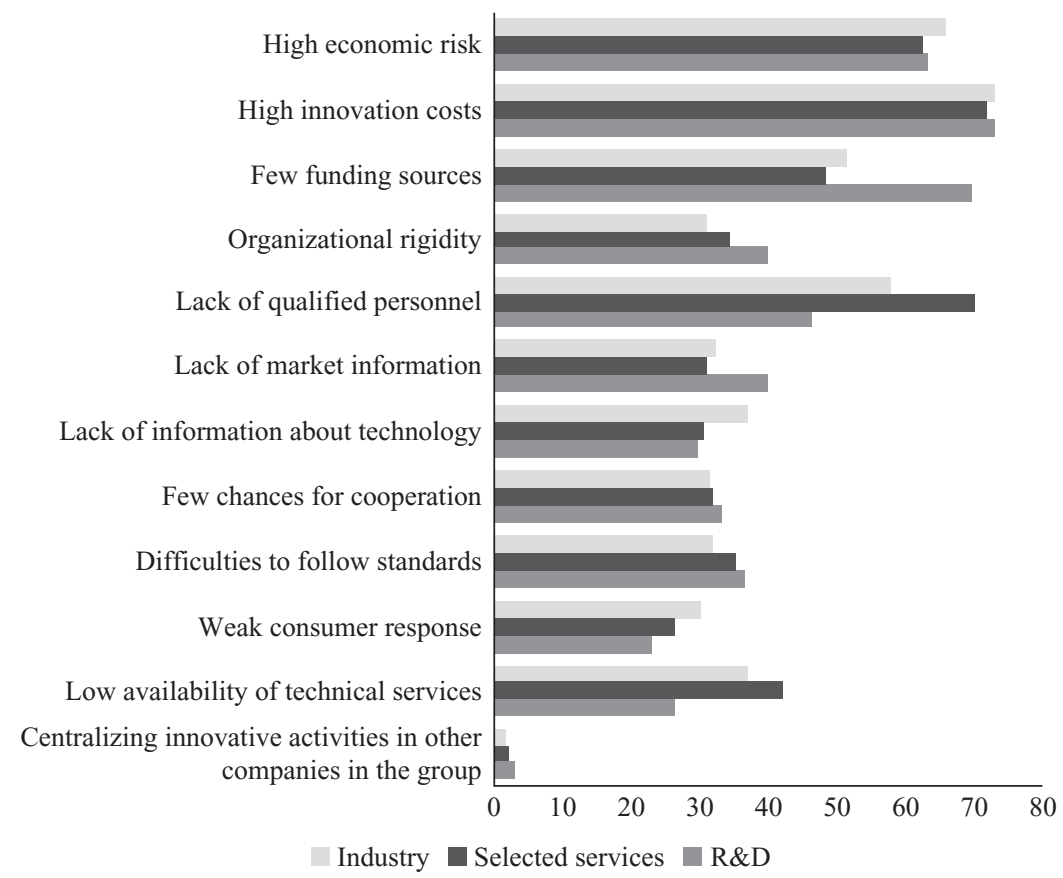

Source: IBGE - Directorate of Surveys, Coordination of Industry, Survey of Technological Innovation (Pintec), 2008.

Figure 2 Problems and obstacles listed by innovative Brazilian firms (2006-2008) 
within the economy and between economies. Therefore, firms located in developed countries manage to finance and carry out innovative activities somewhat differently from firms located in peripheral economies such as Brazil.

Pintec (2008) shows that internal funds bear a greater impact on a firm's investments. That survey reveals that 76 percent of Brazilian industry and service firms have used internal funds over debt or external equity to finance R\&D projects. Unfortunately, given the constraint of internal fund sources, long-term R\&D projects surrounded by high levels of uncertainty tend to be postponed by firms during difficult economic times. In such situations, they will prefer to invest in projects with high returns and low risks, since liquidity preference is higher in peripheral economies.

In Brazil, R\&D projects may be difficult to finance through external sources, since according to Pintec (2008), only 24 percent of firms have used external capital funding from private financial institutions or from the government. External finance is commonly used to fund other innovative activities such as the acquisition of external knowledge, software, machines and equipment, and training. This result shows that Brazilian firms have to access external finance to carry out low-risk activities and to achieve 'more tangible' results, since external finance may be expensive, if at all available. Furthermore, as private banks are averse to financing innovative assets because of the difficulty in evaluating them properly, it may be difficult to obtain external financing.

External financing provided by the Brazilian government can be accessed in different ways. The first is via public agencies or state-owned banks that provide grants - that is, non-reimbursable funds and loans. The second is via subsidies and tax incentives directly available to firms. Government finance resources have been used by only 19 percent of firms, according to Pintec (2008). The data of the survey also pointed out that almost all government funds go towards supporting firms that are already self-sustaining. Firms in the start-up and initial growth stages - those that are more dependent on state support to introduce innovations to the market - have restricted access to this kind of external finance funding. Survey data have also shown that 14.2 percent of industrial firms use government support to buy machinery and equipment, while 0.8 percent use it to finance $R \& D$ projects in cooperation with universities and research centers.

As regards the venture capital market, Ribeiro and Carvalho (2008) report that this kind of funding is still not sufficiently developed in Brazil. Generally, it concerns firms that are in the initial and sustained growth stages. On the other hand, in the USA, a great share of this funding is directed at start-up firms. The authors also say that structural and economic problems such as excessive bureaucracy and long inflationary periods influence the risk-aversion behavior of agents in Brazil.

Obviously, the fragility of Brazilian financial arrangements reinforces NIS immaturity. If we think back to Veblen, it is easy to see that the Brazilian financial structure frames part of its NIS, which then affects the behavior of local firms. At the same time, the behavior of those firms influences the institutions in the NIS. Routine (habit) and bounded rationality (instinct) firms at the periphery usually finance their innovation activities either through internal funds or through banks, while firms in a developed economy seek other sources of financing such as venture capital. Furthermore, as there are no advanced securitization markets in the periphery, it is not so easy to turn an illiquid asset into a liquid one in this kind of economy. Each country's NIS constrains the way firms finance innovation, thus also constraining these firms' development.

It is also worth remembering that inside Minsky's cycle, developing economies can also be seen as Ponzi structures, given the risk of granting credit. Hence, innovative activity in Brazil can be defined as an activity of Ponzi funding within a Ponzi structure. 
This implies a double restriction on credit access, exacerbated by the relation preference shown in the equation of the own rate of interest (4.3). Even in times of economic boom, the funding of innovative assets is less attractive in Brazil than the funding of the same assets in central economies like the USA.

\section{CONCLUSION}

This article discussed how cycles of international financial systems affect investments in innovation and make such a process more difficult in countries with less-developed NIS. We conclude that this occurs partly because banks follow the logic of asset choice proposed by Keynes. That is, they consider profitability and their liquidity preference when choosing assets. Peripheral economies face the problems of uncertainty and liquidity preference of local markets that inhibit investments in innovative assets. Therefore, they encounter many difficulties when funding R\&D projects not only in moments of economic downturn but also in moments of economic growth and market euphoria. In this case, investments will be directed to central economies where the own rate of interest of an asset is higher than for the same asset in peripheral economies. Thus, the structure of international financial systems affects credit-granting both domestically and worldwide.

Developed countries like the USA have a well-structured NIS and so they are in the core of international financial systems, where there are enough financial resources to fund R\&D projects and develop high-tech products and services. On the other hand, the Brazilian NIS is formed by a relatively less-developed financial structure and located in the periphery of international financial systems. This reduces the availability of financial resources in the local market and influences the investments made by firms. In fact, uncertainty decreases the volume of money available to fund innovation, since agents tend to prioritize liquidity. Data from R\&D investments made in Brazil demonstrate that firms' internal funds are the main source of R\&D project funding. On the other hand, external finance tends to fund activities that are seen as being less risky.

This study also shows that innovation in the periphery tends to be twice ignored by asset allocation in the world's capitalist system. That is, it is ignored due to the illiquid nature of innovative assets and to the uncertainty of the peripheral economy. Thus, structural constraints will impose limits on firms in less-developed countries in their quest to fund their R\&D projects.

\section{REFERENCES}

Amado, A.M. (2000): Limites monetários ao crescimento: Keynes e a não neutralidade da moeda, in: Ensaios FEE, 21(1), 44-81.

Caprio Jr., G., Demirgüç-Kunt, A. (1998): The role of long-term finance: theory and evidence, in: The World Bank Observer, 13(2), 1-31.

Carpenter, R.E., Petersen, B.C. (2002): Capital market imperfections, high-tech investment, and new equity financing, in: The Economic Journal, 112, 54-72.

Dow, S.C. (1993): Money and the Economic Process, Aldershot: Edward Elgar.

Fabrizio, K.R., Mowery, D.C. (2007): The federal role in financing major innovations: information technology during the postwar period, in: Lamoreaux, N., Sokoloff, K. (eds), Financing Innovation in the United States, 1870 to Present, Cambridge, MA: MIT Press, 283-316.

Freeman, C., Soete, L. (1997): The Economics of Industrial Inovation, London: Routledge, 3rd edn. 
Hall, B.H. (2002): The financing of research and development, in: Oxford Review of Economic Policy, 18(1), 35-51.

Hodgson, G. (2004): The Darwinian mind of Thorstein Veblen, in: Hodgson, G., The Evolution of Institutional Economics: Agency, Structure and Darwinism in American Institutionalism, London: Routledge.

Keynes, J.M. (1936): The General Theory of Employment, Interest and Money, London: Macmillan.

Keynes, J.M. (1937): The 'ex ante' theory of the rate of interest, in: Economic Journal, 47(188), 663-669.

Knight, F.H. (1965): Risk Uncertainty and Profit, New York: Harper and Row.

Lamoreaux, N., Sokoloff, K. (eds) (2007): Financing Innovation in the United States, 1870 to the Present, Cambridge, MA: MIT Press.

Langlois, R. (1994): Risk and uncertainty, in: Boettker, Peter J. (ed.), The Elgar Companion to Austrian Economics, Northampton, MA: Edward Elgar, 118-122.

Minsky, H. (1986): Stabilizing an Unstable Economy, New Haven: Yale University Press.

Nelson, R., Rosenberg, N. (1993): Technical innovation and national systems, in: Nelson, R. (ed.), National Innovations Systems: A Comparative Analysis, New York: Oxford University Press.

Nelson, R.R., Winter, S.G. (1982): An Evolutionary Theory of Economic Change, Cambridge, MA: Havard University Press.

Paula, L.F. (1999): Teoria da firma bancária, in: Lima, Gilberto Tadeu, Sicsú, João, Paula, Luiz Fernando Rodrigues (eds), Macroeconomia Moderna: Keynes e a Economia Contemporânea, Rio de Janeiro: Ed. Campus, 171-189.

Pintec (2008): Survey of Technological Innovation, Rio de Janeiro: IBGE, URL: http://www. ibge.gov.br.

Resende, M.F.C. (2005): O padrão dos ciclos de crescimento da economia brasileira: 1947-2003, in: Economia e Sociedade, Campinas, 14(1), 25-55.

Resende, M.F.C., Raposo, D.A. (2008): National Innovation System, competitiveness and economic growth, Belo Horizonte: UFMG/Cedeplar Working Paper, No. 325.

Ribeiro, L.L., Carvalho, A.C. (2008): Private equity and venture capital in an emerging economy: evidence from Brazil, in: Venture Capital, 10(2), 111-126.

Roberts, E.B. (1991): Entrepreneurs in High Technology - Lessons from MIT and Beyond, New York: Oxford University Press.

Schumpeter, J.A. (1911 [1934]): The Theory of Economic Development, London: Oxford University Press.

Suzigan, W., Albuquerque, E.M. (2008): A Interação entre em Universidades e Empresas em Perspectiva Histórica no Brasil, UFMG Working Paper, No. 329.

Veblen, T. (1899): The theory of leisure closure: an economic study in the evolution of institutions, URL: http://xroads.virginia.edu/ hyper/VEBLEN/chap08.html.

Veblen, T. (1909): The limitations of marginal utility, in: Journal of Political Economy, 17(9), $620-636$.

Veblen, T. (1961): The Place of Science in Modern Civilizations and Other Essays, New York: Russel \& Russel. 